\title{
Impact of Service Marketing Mix in the Banking Sector: A Study of Private Commercial Banks in Dhaka City, Bangladesh
}

\author{
Md. Maniruzzaman
}

\begin{abstract}
Marketing mix is simply defined as some factors or combination of components which are controlled by the organization in order to promote the product and brand for satisfying customer. The main objective of this study to know the customer needs, wants and demand as to an organization can design the right products, set up the right price, at the right place with proper promotion in satisfactory manner. Service Marketing is very significance due to excessive competition, service differentiation, customer awareness, easy access of information, customer synchronization etc. Banking sector in Bangladesh is very pivotal in service industry where majority of the people have direct or indirect involvement. Service Marketing Mix in Banking Sector is also known as extended marketing mix which is significant part of effective service design. This study is also attempted to collect, analyze \& evaluate the Marketing Mix in the Banking Sector in Bangladesh. This study suggests a marketing Mix that could be inherent by direct marketing, personal marketing, one to one marketing, network marketing and social marketing elements for adding value in the Banking Channels. This paper is also aimed at finding out the additional Ps behind the 7Ps of service marketing to differentiate, customize and more value addition to the customer. The present banking sector in Bangladesh is even relying on traditional banking rather Modern Banking with holistic approach. Most of the Bank has no separate marketing division to analyze and develop the customer want, need \& demand in Bangladesh.
\end{abstract}

Index Terms - Banks, Marketing Mix, 04 Ps, 07 Ps, Service Marketing, Banking sector, Bangladesh

\section{INTRODUCTION}

Product, Price, Place \& Promotion are the traditional element of marketing mix but in service sector, there are some additional Ps usually 03 Ps like People, process \& physical evidence. Though the Bank basically delivers the financial service, marketing mix in this sector can be more extended than the existing service marketing mix prevailing in different service sector. As we all know that the Banking service is very much sophisticated, time bound, confidential and sensitive. Here financial interest is co-related with service delivery. So, Banks have to be conscious more in the time of providing service. Marketing mix has two kinds of benefits; one is that it is used as tools to enable one to see the job of marketing manager. Basically, it shows trade off one's

Md. Maniruzzaman, Credit Risk Management Division (SME), United Commercial Bank Limited, Dhaka, Bangladesh competitive strengthens position over others in the marketing mix. Another advantage of the marketing mix is that it assists to reveal different dimension of the marketing manager's job. Managers have to distribute resources which are available among unlimited demands, and the marketing manager will in turn allocate these available resources among the various competitive devices of the marketing mix. Moreover, marketing mix in banking sector creates the value for the customer by which a customer is satisfied more to get his/her service and creates value laden relationship with this particular Bank. In banking sector in Bangladesh, Marketing practice is exercised up to the certain limit but in this globalization and in the era of competition, it is difficult to survive them without exercising vast fair marketing practice. Now, the customers expect more on their service not only core product but also augmented products. Customer wants to make transaction with Bank by confidentially, deliberately and rapidly. Customers also seek the competitive price, bundle of benefits, newness in product offering and what not. Bank customers demand more privilege than any other service sector. Now they want to make transaction by sitting in the home and don't agree with waiting in service queue even in a minute. As a result, Banks have to think new strategy and policy to meet the customer needs, wants \& demand.

\section{LITERATURE REVIEW}

Banking sector is the significance financial institution where service Marketing plays pivotal issues to satisfy the customer and gain competitive advantages. There are many studies and research endeavors among the scholars throughout the world. Some of the relevant studies are being pointed below-

It is known that Borden (1964) introduced the marketing mix concept through describing a marketer as a mixer of ingredients in practicing company activities. However, the formal use of the marketing mix model in the marketing context was presented by McCarthy (1964) who proposed the 4Ps of the marketing mix ingredients model, which are product, price, promotion and place. A marketer should make a combination of these elements to create a distinctive marketing mix by which a company may achieve its objectives. McCarthy`s model has become one The 7Ps Classification.

Levitt, T. (1974); explains that all the techniques and strategies of marketing are used so that ultimately they induce the people to do business with a particular bank. To create and keep a customer means doing all those things so that people would like to do business and continue to do it with a 
particular bank rather than with the competitors. A business is not a business if it cannot stay in business. It cannot stay in business if it does not attract and hold enough customers, no matter how efficiently it operates.

Turnbull, Peter W. (1982), places the branch bank manager in a central position in the business in respect of the marketing efficiency of the banks at the local level. The study identified three reasons which underlie the lack of marketing orientation: motivation, ability and time and says that banks need to move quickly to ensure that branch bank managers Can speedily meet the challenge. It was suggested that managers be given knowledge inputs on the principles of marketing and develop in them the commitment to implementing the principles in practice

Jha, S.M. (1982); in his book "Services Marketing", deals with bank marketing, marketing research, market segmentation, marketing mix for banking services, bank marketing in Indian environment. The author feels that despite the existence of commercial banks, which were established to make available timely and adequate services to the customers. Banks suffered due to lack of adequate and appropriate strategies for marketing their financial services. He explained the marketing mix strategies such as product mix, place mix, promotion mix, price mix, people mix, physical evidence mix and processes mix for the service sector

Ravisankar, T.S. (1985); in a study on "Marketing Strategies and Planning for Business Growth in Banks" says that the marketing plan for banking services should be supported by appropriate marketing strategies. He suggests that marketing strategy for banks must be oriented towards customers-current and potential as well.

Radhakrishnan, S.(1987); conducted a study on 'Marketing of Banking Services, Constraints, Challenges and Strategy' and found that mixed banking, complaints from customers about bank charges, competition from nonbanking financial companies and growing investment consciousness of the public are some of the impediments to bank marketing. It is suggested that the branch manager can design appropriate marketing strategy through identification of customer needs and service efficiency with appropriate differentiation by understanding customer behavior.

Lewis (1993) said that customers perceive service quality in a subjective (sometimes irrational and sentimental) way and in clearly human terms. Zeithaml et al. (1990), and Zeithaml and Parasuraman (2004) opined that unlike products; the quality of services is evaluated by customers not only by the service outcome (core service), but also by the production and delivery process as well as by the 'peripherals' related to the service

Barney (2002) argued that a firm experiences competitive advantages when its actions within a given industry or market create economic value and when few competing firms are engaging in similar actions. According to Barney, competitive advantage is tied to performance. A firm obtains above normal performance when it generates greater than expected value from the resources it employs. However, Porter (1996) argues that competitive strategy is simply about being different. It means deliberately choosing a different set of activities to deliver a unique mix of value. Competitive strategy refers to strategic positioning which can be based on customers' needs, customers' accessibility, or the product mix. Strategy therefore is the creation of a unique and valuable position involving a different set of activities (Spulber,2009)

Mehta (2010) in his article" Personal Selling-A Strategy for promoting Bank Marketing "reported that there is lack of Marketing Communication in Indian Banks .He suggested for adopting banks suitable marketing promotion strategies for better business. He emphasized that on adoption of personal selling as a strategy for marketing promotion in Banks the banking business can improve considerably

According to Levie (2006), the aim of the development of an organization's marketing strategy development is to establish, build, defend and maintain its competitive advantage

\section{NEED FOR STUDY}

There are some momentous factors that demands for Service Marketing Mix study in Banking sector in Bangladesh which are given below-

\# Inappropriate pricing strategy

\# Front line service providers are not well trained

\# Offering mass product \& service by the Bank

\# Traditional channel of distribution of the service

\$ Customer dissatisfaction for delaying service

\# A little or no promotional effort by the Bank

\# Faulty process of services and physical evidence

\section{OBJECTIVE OF THE STUDY}

There are some momentous factors that demands for Service Marketing Mix study in Banking sector in Bangladesh which are given below-

\# To design the customized products

\# To deliver the excellence service

* To gain competitive advantages

* To design the service delivery channel and way of promotions.

* Proper pricing strategy and service process with adequate service cape.

\section{RESEARCH QUESTIONS}

The researcher formulated the problem of the study by the following questions:

i. What are natures of Bank services that help the Banks to achieve the competitive advantage in the Bangladeshi Banking Industry?

ii. Which pricing strategies could be applicable to achieve the competitive advantage in Private Commercial Banks in Dhaka?

iii. Which is the best tool to communicate with the actual and potential customers in order to build the competitive advantage in Private commercial Banks in Dhaka?

iv. How could the Private Banks in Dhaka City use the efficient distribution channels to achieve the competitive advantage?

v. Could the employees in Commercial Banks create a high performance in the Banking industry in Dhaka City?

vi. Are the physical evidences in Private Banks in Dhaka considered as critical factors to build a competitive advantage in Dhaka City in banking industry?

vii. What are the best practice methods of services processing could be applicable to achieve the 
competitive advantage in Banking Industry in Dhaka City?

\section{RESEARCH HYPOTHESIS}

The main hypotheses of the study are:

There is no statistical significance at $(0.05 \geq \alpha)$, between combined 7 marketing mix element (Product or service, Price, Distribution, Promotion, Service provider, Physical evidence, Process) and competitive advantage.

From this hypothesis we established the following:

\# H01: There is no statistically significant at $(0.05 \geq \alpha)$, between Banking products or services and competitive advantage in Private Commercial Bank in Bangladesh

\# H2: There is no statistically significant at $(0.05 \geq \alpha)$, between Banking products or services price and competitive advantage in Private Commercial Bank in Bangladesh

\# H03: There is no statistically significant at $(0.05 \geq \alpha)$, between Distribution and competitive advantage in Private Commercial Bank in Bangladesh

\# H04: There is no statistically significant at $(0.05 \geq \alpha)$, between promotion and competitive advantage in Private Commercial Bank in Bangladesh

\# H05: There is no statistically significant at $(0.05 \geq \alpha)$, between people or service provider and competitive advantage in Private Commercial Bank in Bangladesh

* H06: There is no statistically significant at $(0.05 \geq \alpha)$, between physical evidence and competitive advantage in Private Commercial Bank in Bangladesh.

\# H07: There is no statistically significant at $(0.05 \geq \alpha)$, between process and competitive advantage in Private Commercial Bank in Bangladesh

\section{STUDY MODEL}

In this study model, it has been observed that the independent variables include- Product, price, promotion, place, people, physical evidence, process. Dependent variables are competitive advantages and customer satisfaction and moderating variable is Demographic/behavioral factors.

\begin{tabular}{|l|}
\hline Product/Service \\
\hline Price/Value \\
\hline Promotion \\
\hline Place \\
\hline People/Service provider \\
\hline Physical Evidence \\
\hline Process \\
\hline
\end{tabular}

\section{RESEARCH METHODOLOGY}

1. Collection of Data:

i) Structured questionnaires were distributed to the various customer of different private bank and explained the purpose of the study. The distributed questionnaires were 140 and returned 102 valid questionnaires which is $73 \%$ response rate. It is mentionable here that we found 10 nos. of different Bank customer in this study.

ii) Analysis of different literature regarding the service marketing mix

iii) To observe the service marketing mix in capital city Dhaka.

iv)To collect data from reference group, friends and acquaintances who are related with Bank

v) Personal interview of marketing people of different bank in capital city Dhaka.

2. Sampling Unit:

The customer's age, sex, race, location, income, region and educational background are included here.

3. Nature of Data: Primary data \& secondary data

4.Type of questionnaire:

Structure questionnaire with proper scaling

5. Type of questions: Likert scale \& multiple choice questions.

6. Data analysis instrument: Statistical software Statistical Package for the Social Sciences (SPSS) was used for analyzing the data. Descriptive statistics were used in this study.

7. Validity:

Research scholars of different Universities were consulted to examine the relevancy of the of the questionnaire to the study objectives.

8. Reliability:

Cronbach's alpha was used to determine the reliability of the measurement set, the value o (a) $86.70 \%$ which is considered to be higher than the level of acceptability which is $60 \%$, this indicates that the measurement set used in the study is reliable (Naresh K. Malhotra)

\section{Marketing}

\section{CONCEPTUAL FRAMEWORK}

Marketing is the process by which companies engage customers, build strong customer relationships and create customer value in order to capture value from customers in return (Philip Kotler)

Marketing is the process of identifying customer needs, creating value and capturing value from customer by delivering desired products and services

Services are deeds, processes, and performance provided or co-produced by one entity or person for another entity or person.

According to Philip Kotler, service is an action or an activity which can be offered by a party to another party, which is basically intangible and can not affect any ownership. Service may be related to tangible product or intangible product.

\section{Services Marketing}

Services Marketing is a sub field of marketing, which can be split into the two main areas of goods marketing and services marketing.

Service marketing includes: telecommunications services, financial services, all types of hospitality services. The range of approaches and expressions of a marketing idea developed 
with the hope that it could be effective in conveying the ideas to the diverse segments of people who receive it.

\section{CHARACTER OF BANK SERVICE}

1.Perishability:

Service is highly perishable in nature and time has great significance in service marketing.

2.Fluctuating Demand:

Service demand is highly variable in different point of time. Demand can be changed within a day, hour, weeks, season etc. Sometimes services have pick demand or overfull demand and sometimes have low demand or zero demand.

3. Intangibility:

Service provides benefit or bundle of benefits, we may satisfy by taking service but no one can touch or catch the service. It can be felt during consumption.

4.Inseparability:

Service cannot be separated from the providers. Providers renders service by utilizing his expert, experience and efficiency. For example, Treatment is not possible without presence of Patient \& doctor.

5.Heterogeneity:

Service may not be homogeneous to all. Service price and benefit may be varies person to person

6. Pricing of Services:

Pricing of service depends on various factor like demand fluctuation, availability of service, time of service, perishability, market competition etc. Quality of service is the other major factor for setting the service price but it cannot be carefully standardize.

7.Service quality is not statistically measurable:

Service quality relates with customer satisfaction by using a particular products or service. How a customer is benefited or to what extent is benefited by taking service with exchange of money, it depends on customers want and their latent pre set up slandered. So it is qualitative measurement, it doesn't express statistically. Direct interacting with customer by employees or marketing people is very fruitful, special and important. So holistic marketing approach is very important to satisfy the customer need in service marketing

\section{FUNDAMENTAL DIFFERENCES BETWEEN PHYSICAL GOODS AND SERVICES}

\begin{tabular}{|l|l|}
\hline \multicolumn{1}{|c|}{ Goods } & \multicolumn{1}{c|}{ Services } \\
\hline A physical commodity & A process or activity \\
\hline Tangible & Intangible \\
\hline Homogenous & Heterogeneous \\
\hline $\begin{array}{l}\text { Production and distribution } \\
\text { are separation from their } \\
\text { consumption }\end{array}$ & $\begin{array}{l}\text { Production, distribution } \\
\text { and consumption are } \\
\text { simultaneous processes }\end{array}$ \\
\hline Can be stored & Cannot be stored \\
\hline $\begin{array}{l}\text { Transfer of ownership is } \\
\text { possible }\end{array}$ & $\begin{array}{l}\text { Transfer of ownership is } \\
\text { not possible }\end{array}$ \\
\hline
\end{tabular}

\section{SERVICE MARKETING EXCELLENCE}

Service marketing excellence is the outcome of some combined factors which are external Marketing, internal marketing and interactive marketing. External marketing means appropriate methods of pricing, distribution channel and promotional activities in order to satisfying the customer. Internal marketing means increasing efficiency, loyalty, accountability, awareness, dedication, cooperation etc. within the organization among the employees through counseling, training and motivation. Interactive marketing covers the employee's skill and wisdom in the time of serving to the client

\section{SERVICE MARKETING MIX}

Service marketing mix is also called extended marketing mix which consist of some elements or combination of factors that can be controlled by an organization

\section{A. Product}

Products in banking sector are different and sometimes complex in nature. This is not like physical products like chips, soap, chocolate, detergent etc. Service cannot be measured like physical products. Rather it offers bundle of benefits. Banking service or products can be two types one is deposit products another is lending products. Deposit products can be various name, nature, duration etc. and lending products can also be different like home loan, personal loan, car loan, SME loan and what not. Each product can be the different name, symbol and different customer segment. Product design in banking sector is as crucial due to product act as blue print of escalation and market attraction.

\section{B. Place}

Place means where a service organization provide their service to the customer. So place or distribution of service is very vital to satisfy the customer. It should be easy access, friendly environment and free from all types of hassle. An organization aims at distributes their all products or service at the edge of the customer.

\section{Promotion}

Promotion is very important element in service marketing mix to persuade the customer about the product or brand. There are many tools and techniques to promote the brand into the market like direct marketing, personal selling, advertising, fair \& exhibition, sales promotion, publicity, event marketing etc. The objective of the promotion is to increase customer awareness, generate sales, create brand loyalty, enhance market coverage etc.

\section{Pricing}

Pricing is the important variables in marketing mix. Right price plays pivotal role in generating of sales and making profit of the organization. Customer is very price sensitive in the time taking service as they have lots of options in hand. So, an organization has to take vital decision in the time of setting price of the products.

\section{E. Physical evidence:}

Physical evidence is very important factor in service marketing Mix. Physical evidence can be categorized in two important parts one is Peripheral evidence another one is essential evidence. Peripheral evidence is the evidence which is absolutely possessed as a part of the purchase of service. This evidence has no independent value at all. A Bank cheque book has no value until backed by the fund transfer and it represents the storage of service. It has just ensured that the confirmation of service in particular period or a particular time. Besides, a bank has much peripheral service to the 
customer like welcome gift, calendar, notepad, pens, Card holder etc.

F. People: Right people in right place is the important element of service marketing concept. Service usually delivers through the people or a group of people. Service organization like a Bank people can differentiate the service through excellent presentation and comprehensive delivery skill with smiling face. People or delivery staff should have appropriate interpersonal skill, aptitude and service knowledge.

G. Process: Service Process means flow of services or how a service is procured or provided to the customer. It involves procedure, technique, tasks, time, mechanism, mode, routine, duration etc. by which a service is delivered to the customer. Service process should be faster, adequate, trustworthy, fair and customer friendly

\section{TEST OF HYPOTHESIS \& RESULT}

\section{Table\# 01}

\begin{tabular}{|l|c|c|c|}
\hline $\begin{array}{l}\text { Statement related } \\
\text { Service/products }\end{array}$ & Mean & $\begin{array}{c}\text { Std. } \\
\text { Deviatio } \\
\mathrm{n}\end{array}$ & $\begin{array}{l}\text { Ran } \\
\mathrm{k}\end{array}$ \\
\hline $\begin{array}{l}\text { 1-The Bank offers } \\
\text { excellence services }\end{array}$ & 3.6961 & .93119 & 4 \\
\hline $\begin{array}{l}\text { 2-The Bank offers } \\
\text { customized financial } \\
\text { product }\end{array}$ & 3.8627 & .93384 & 3 \\
\hline $\begin{array}{l}\text { 3-The Bank offers } \\
\text { complementary service } \\
\text { like cash back offer, } \\
\text { credit card discount offer, } \\
\text { bill paying service etc. } \\
\text { along with financial } \\
\text { products/services }\end{array}$ & 3.5490 & .96089 & 1 \\
\hline $\begin{array}{l}\text { 4-The Bank offers } \\
\text { different event service }\end{array}$ & 3.2353 & .71996 & 6 \\
\hline $\begin{array}{l}\text { 5-The Bank advises or } \\
\text { counsel about the offered } \\
\text { products }\end{array}$ & 3.3235 & .84621 & 5 \\
\hline $\begin{array}{l}\text { 6-Terms \& condition of } \\
\text { service are flexible }\end{array}$ & 4.0196 & .94377 & 2 \\
\hline
\end{tabular}

Table- 01 , discussed the results of hypothesis number -01 .

Respondents had to provide if there are any relationship between Bank products and services and the competitive advantage in Bangladesh Banking Industry. The table results shows that there is a relationship between Bank products and services and the competitive advantage in Bangladesh Banking sector, also the respondents rated the complementary service like cash back offer, credit card discount offer, bill paying service etc. are important

\section{Table\# 02}

\begin{tabular}{|c|c|c|c|}
\hline Statement related Price & Mean & $\begin{array}{c}\text { Std. } \\
\text { Deviation }\end{array}$ & $\begin{array}{c}\mathrm{Ra} \\
\mathrm{nk}\end{array}$ \\
\hline $\begin{array}{l}\text { 7-The Price of service } \\
\text { equals the quality of } \\
\text { product/service that you } \\
\text { receive }\end{array}$ & 3.7353 & .95364 & 3 \\
\hline
\end{tabular}

\begin{tabular}{|l|l|l|l|}
\hline $\begin{array}{l}\text { 8-The price equal to the } \\
\text { benefit that you receive }\end{array}$ & 3.6569 & .99000 & 1 \\
\hline $\begin{array}{l}\text { 9-The Bank service prices } \\
\text { are reasonable }\end{array}$ & 3.6471 & .91896 & 4 \\
\hline $\begin{array}{l}\text { 10-The Bank offers } \\
\text { excellent rate of interest for } \\
\text { deposit products }\end{array}$ & 3.4118 & .90491 & 5 \\
\hline $\begin{array}{l}\text { 11-The Bank offer flexible } \\
\text { pricing strategy }\end{array}$ & 3.3333 & .87125 & 6 \\
\hline $\begin{array}{l}\text { 12-The Banks offer } \\
\text { competitive prices }\end{array}$ & 3.7647 & .97672 & 2 \\
\hline
\end{tabular}

Table- 02, discussed the results of hypothesis n number 02 .

Respondents had to provide if there is any relationship between Bank service prices and the competitive advantage in Dhaka City, Bangladesh. The table results show that there is a relationship between Bank products \& services and the competitive advantage in Bangladesh Banking sector. Answers show that the respondents pay attention to the Point number 8 which is talked.

\section{Table\# 03}

\begin{tabular}{|l|c|c|c|}
\hline \multicolumn{1}{|c|}{ Statement related Place } & Mean & $\begin{array}{c}\text { Std. } \\
\text { Deviation }\end{array}$ & Rank \\
\hline $\begin{array}{l}\text { 13-The Bank adopts modern } \\
\text { Technology in delivery the } \\
\text { service \& information }\end{array}$ & 3.6569 & .92806 & 2 \\
\hline $\begin{array}{l}\text { 14-The Bank has electronic } \\
\text { Banking \& Mobile Banking } \\
\text { system }\end{array}$ & 3.5392 & .90839 & 3 \\
\hline $\begin{array}{l}\text { 15-The Bank has multilevel } \\
\text { service delivery system }\end{array}$ & 3.5588 & .90732 & 4 \\
\hline $\begin{array}{l}\text { 16-The Bank comes to the } \\
\text { people for informing their } \\
\text { new service }\end{array}$ & 3.4412 & .83930 & 5 \\
\hline $\begin{array}{l}\text { 17-Service delivery of the } \\
\text { Banks are consumer } \\
\text { convenient }\end{array}$ & 3.2941 & .82760 & 6 \\
\hline $\begin{array}{l}\text { 18-The Bank Service queue } \\
\text { is so long and time } \\
\text { consuming. }\end{array}$ & 3.6765 & .93514 & 1 \\
\hline
\end{tabular}

Table- 03, discussed the results of hypothesis number 03 .

Respondents had to provide if there is any relationship between Banks Place (Distribution), and the competitive advantage in banking sector in Bangladesh. The table results show that there is a relationship between Bank products and services and the competitive advantage in banking sector in Bangladesh. Responds consisted of point number 18 which is Bank Service queue is so long and time consuming.

\section{Table\# 04}

\begin{tabular}{|l|c|c|c|}
\hline $\begin{array}{l}\text { Statement related } \\
\text { Promotion }\end{array}$ & Mean & $\begin{array}{c}\text { Std. } \\
\text { Deviation }\end{array}$ & Rank \\
\hline $\begin{array}{l}\text { 19-The Bank uses effective } \\
\text { way of promotion \& } \\
\text { advertising }\end{array}$ & $\begin{array}{l}7.362 \\
\text { 20-The Bank focuses on }\end{array}$ & .79340 & 6 \\
$\begin{array}{l}\text { direct marketing as a } \\
\text { effective means of } \\
\text { promotion }\end{array}$ & 2 & .90839 & 2 \\
\hline 21-The Bank has distinctive & 3.421 & .81370 & 5 \\
\hline
\end{tabular}


Impact of Service Marketing Mix in the Banking Sector: A Study of Private Commercial Banks in Dhaka City, Bangladesh

\begin{tabular}{|l|c|c|c|}
\hline $\begin{array}{l}\text { brand compared to } \\
\text { competitors }\end{array}$ & 6 & & \\
\hline $\begin{array}{l}\text { 22- Information is available } \\
\text { in Bank website \& in }\end{array}$ & 2.490 & .92002 & 1 \\
internet & 2 & & \\
\hline $\begin{array}{l}\text { 23-Service delivery of the } \\
\text { Banks are consumer } \\
\text { convenient }\end{array}$ & 4.431 & .82666 & 4 \\
\hline $\begin{array}{l}\text { 24-The Bank provides } \\
\text { promotional offers from } \\
\text { time to time }\end{array}$ & $\begin{array}{l}3.451 \\
0\end{array}$ & .85164 & 3 \\
\hline
\end{tabular}

Table- 04, discussed the results of hypothesis number 04 .

Respondents had to provide if there is any relationship between Bank promotion and the competitive advantage in banking sector in Bangladesh. The table results shows that there is a relationship between Banking products and services and the competitive advantage in banking sector in Bangladesh. Respondents agreed that the information is available in Bank website \& in internet

\section{Table\# 05}

\begin{tabular}{|c|c|c|c|}
\hline $\begin{array}{ll}\text { Statement } & \text { related } \\
\text { People } & \\
\end{array}$ & Mean & $\begin{array}{c}\text { Std. } \\
\text { Deviation }\end{array}$ & Rank \\
\hline $\begin{array}{l}\text { 25-The Bank has skilled } \\
\text { manpower and } \\
\text { competent personnel \& } \\
\text { capable of providing } \\
\text { service to the customer }\end{array}$ & 3.3333 & .74904 & 6 \\
\hline $\begin{array}{l}\text { 26-Personnel seeks to } \\
\text { good relations with the } \\
\text { customer }\end{array}$ & 3.5392 & .86370 & 2 \\
\hline $\begin{array}{l}27-\mathrm{I} \text { feel that service } \\
\text { provider seek to provide } \\
\text { excellent service to my } \\
\text { needs \& desires }\end{array}$ & 3.3431 & .80216 & 5 \\
\hline $\begin{array}{l}28 \text { - I feel that the service } \\
\text { provider in the Bank } \\
\text { understand the service } \\
\text { culture }\end{array}$ & 3.5000 & .90925 & 1 \\
\hline $\begin{array}{l}\text { 29-Service delivery of } \\
\text { the Banks are consumer } \\
\text { convenient }\end{array}$ & 3.4314 & .82666 & 4 \\
\hline $\begin{array}{l}\text { 30-Personnel seek to } \\
\text { resolve the problem } \\
\text { rapidly and satisfactorily. }\end{array}$ & 3.4412 & .83930 & 3 \\
\hline
\end{tabular}

Table- 05, discussed the results of hypothesis number 05 .

Respondents had to provide if there is any relationship between People (Service Providers), and the competitive advantage in in banking sector in Bangladesh. The table results shows that there is a relationship between Banking products and services and the competitive advantage in banking sector in Bangladesh, the respondents seeks to be served by people who understand the service culture

\section{Table\# 06}

\begin{tabular}{|l|r|r|r|}
\hline $\begin{array}{l}\text { Statement related } \\
\text { Physical evidence }\end{array}$ & Mean & $\begin{array}{c}\text { Std. } \\
\text { Deviation }\end{array}$ & Rank \\
\hline $\begin{array}{l}\text { 31- The service space and } \\
\text { setting arrangement of the }\end{array}$ & 3.2843 & .78825 & 5 \\
$\begin{array}{l}\text { Bank has psychological } \\
\text { comfort for customer }\end{array}$ & & & \\
\hline
\end{tabular}

\begin{tabular}{|l|l|l|l|}
\hline $\begin{array}{l}\text { 32- The Bank Branch } \\
\text { offers TV news \& } \\
\text { Entertainment in waiting } \\
\text { area }\end{array}$ & 3.5490 & .86319 & 2 \\
\hline $\begin{array}{l}\text { 33- I feel that the material } \\
\text { accessories in the Banks } \\
\text { reflect a social nature }\end{array}$ & 3.3824 & .82106 & 4 \\
\hline $\begin{array}{l}\text { 34- The Bank has security } \\
\text { and safety requirements }\end{array}$ & 3.4804 & .91986 & 1 \\
\hline $\begin{array}{l}\text { 35-The Bank provide } \\
\text { necessary documents what } \\
\text { Ineed }\end{array}$ & 3.3333 & .82454 & 3 \\
\hline
\end{tabular}

Table- 06, discussed the results of hypothesis number 06.

Respondents had to provide if there is any relationship between Banks Physical evidence and the competitive advantage in banking sector in Bangladesh. The table results show that there is a relationship between Bank Physical evidence and the competitive advantage in banking sector in Bangladesh. Answers show that the respondents prefer if security and safety are tighten in the Bank premise

\section{Table\# 07}

\begin{tabular}{|l|r|r|r|}
\hline $\begin{array}{l}\text { Statement related } \\
\text { Process }\end{array}$ & Mean & $\begin{array}{c}\text { Std. } \\
\text { Deviation }\end{array}$ & Rank \\
\hline $\begin{array}{l}36-\text { The Bank offer } \\
\text { standardized service to the } \\
\text { customer }\end{array}$ & 3.1471 & .77584 & 4 \\
\hline $\begin{array}{l}\text { 37- The works flow of the } \\
\text { Bank is really appreciated }\end{array}$ & 3.4216 & .87242 & 1 \\
\hline $\begin{array}{l}38 \text { - The Bank offer } \\
\text { high-class quality services } \\
\text { in comparison with the } \\
\text { competitor Banks }\end{array}$ & 3.3039 & .84184 & 2 \\
\hline $\begin{array}{l}39-\text { Deposit \& withdrawal } \\
\text { money are very smooth }\end{array}$ & 3.2843 & .82507 & 3 \\
\hline
\end{tabular}

Table- 07, discussed the results of hypothesis number 07 . Respondents had to provide if there is any relationship between Bank Process and the competitive advantage in banking sector in Bangladesh. The table results shows that there is a relationship between Bank process flow of services and the competitive advantage in banking sector in Bangladesh, the point which talking about works flow of the Bank attracts the respondents attention

\section{Table\# 8}

\begin{tabular}{|l|c|c|c|}
\hline $\begin{array}{l}\text { Competitive } \\
\text { advantages }\end{array}$ & Mean & $\begin{array}{c}\text { Std. } \\
\text { Deviation }\end{array}$ & Rank \\
\hline $\begin{array}{l}\text { 40- The Bank has } \\
\text { skilled and } \\
\text { competent personnel } \\
\text { and capable of } \\
\text { providing services to } \\
\text { Customer }\end{array}$ & 3.3333 & .74904 & 7 \\
\hline $\begin{array}{l}\text { 41- The Bank offers } \\
\text { high-class quality } \\
\text { services. }\end{array}$ & 3.3039 & .86370 & 3 \\
\hline $\begin{array}{l}\text { 42- The Price equals } \\
\text { the benefits that you }\end{array}$ & 3.7353 & .95364 & 1 \\
\hline
\end{tabular}




\begin{tabular}{|l|l|l|l|}
\hline $\begin{array}{l}\text { receive during you } \\
\text { receive the service }\end{array}$ & & & \\
\hline $\begin{array}{l}\text { 43- The Bank Uses } \\
\text { effective means of } \\
\text { promotion and } \\
\text { advertising }\end{array}$ & 3.3627 & .79340 & 4 \\
\hline $\begin{array}{l}\text { 44- The Bank seeks } \\
\text { to apply modern } \\
\text { technology in the } \\
\text { transfer of money, } \\
\text { payment and } \\
\text { delivery of } \\
\text { information easily. }\end{array}$ & & .92806 & 2 \\
\hline $\begin{array}{l}45-\text { The Bank } \\
\text { services met my } \\
\text { expectations. 3.2157 }\end{array}$ & & .76595 & \\
\hline $\begin{array}{l}\text { 46-The Bank } \\
\text { services satisfied my } \\
\text { perceptions. }\end{array}$ & 3.2647 & .76981 & 5 \\
\hline
\end{tabular}

The last table focuses at the competitive advantage in general from the respondent's perspective; the results show that the respondents agreed on that the Banks services satisfied their perception.

\section{RECOMMENDATION}

In connection with the study, the following suggestions are offered.

\# Products \& services should be design by analyzing customer need, wants and expectation.

\# Customer perception of the services is to be kept in mind by the Bank

\# Appropriate price through knowing customers willingness to pay and competitor's position is to be set for gaining competitive advantages.

\# Service quality is to be ensured by the Bank for gaining competitive advantages

\# Appropriate mode of Distribution of service is to be re-considered again by the Banks

\# Service Marketing communication or integrated service marketing communication is to be followed for competitive advantages.

* All human actors who play a part in service is to be well trained so that employees knowledge and courtesy and their ability to inspire trust \& confidence is going up.

\# Servicescape or physical evidence is to be available and appropriate for customer satisfaction

\# The procedure mechanism and flow of activities should be appropriated and as per customer requirement

\$04 Gaps of service provider should be brought down at minimum tolerance level or balance the gaps for customer satisfaction

\section{LIMITATION OF THE STUDY}

In Dhaka City, huge numbers of Bank customers are performing their daily activities and Banks also try to differentiate the services, even they offers service package with adequate designing of the products, setting competitive price, doing right channel of distribution, use right way of promotional activities through creating proper service cape $\&$ process flow by their trained employees. As the competition is increasing in the market, Banks continuously tries to offer best to retain the existing customer and attracting new customer.

Every research works have some limitations, so this research work is not free from error or fairly accurate in spite of giving best efforts. We know that the secondary sources of data are not available. Every employee as well as customer is busy with his/her regular activities. Therefore, some of the employees and customers are not able to give the accurate information. Besides, time bound of the research is another factor of limitation

\section{CONCLUSION}

Now days, Service sector is being increased tremendously and it is hardly found pure manufacturing or trading organization. So service involved someway to run the business into the market. However, financial organization like Banks is pure service organization where service marketing play pivotal roles to satisfy the customer. Bank can achieve competitive advantages if they follow proper practice of service marketing mix elements. With the increase of number of banks, customer literarily about banking, cost \& time sensitiveness of the customers are also increased tension of Bank CEO to rethink the traditional marketing into modern digitalized marketing mix

\section{SCOPE OF FUTURE RESEARCH}

Areas The researchers suggest the following future studies: Apply this study on other services sectors in order to generalize and validate the results of this study.

This study concerted only in Dhaka City and very small size of sample. Further study can be with more samples and with wide geographical areas

Due to time \& budgetary constraint, huge data collection and using wide statistical testing were not possible. Further research will solve these issues and conclude exclusive report.

\section{REFERENCES}

[1] Jha, S.M. (1982). "Services Marketing”. Himalaya Publishing House, Mumbai, p. 47.

[2] Kotler, P., \& Armstrong, G. (2018). Principles of marketing (17th ed.). Pearson Printice Hall.

[3] Lovelock, C. 2001. Services Marketing People,Technology, Strategy', Fourth Edition, Prentice Hall.

[4] McCarthy, J. 1964. Basic Marketing: A Managerial Approach', Second Edition, Richard D. IRWIN, INC.

[5] MALHOTRA, N. K. (2006). Marketing Research: An Applied Orientation, Harlow', Fifth Edition, Prentice-Hall India.

[6] Zeithaml, V.A., Bitner, M. J., \& Gremler, D. D. (2006). Service marketing integrating customer focus across the firm (4th ed.). MC grew hall.

[7] Zeithaml, V.A., Bitner, M. J., Gremler, D. D. \& Pandit, A. (2013) Service marketing: integrating customer focus across the firm (6th ed.). MC grew hall.

[8] Akaah, I. and Riordan, E. 1988. Applicability of Marketing Knowledge in the Third World', International Marketing Review, 5(1):41-55

[9] Akroush, M. (2011). The 7ps classification of the services marketing mix revisted: An empirical assessment of their generalisability, applicability and effect on performance - evidence from Jordans services organizations. Jordan Journal Of Business, 7(1), 116-146. 
[10] Akroush, M. 2006. The Services Marketing Mix Paradigm:Is It Still Appropriate for Today's Service Businesses? AL-Balqa' Journal for Research and Studies, 11(2), June):49-74.

[11] AL-Dmour, H. and Ayesh, H. 2005. The effect of the marketing mix elements of five star hotels on the perceived image by Tourists: a comparative study, Jordan Journal of Business Administration,

1(1):101-120

[12] Amis, J., Slack, T. and Berrett, T. 1999. Sport Sponsorship As A Distinctive Competence, European Journal of Marketing, 33(3/ 4):250-272.

[13] Berry, L. L.; Kehoe, W. J. and Lindgreen, J. H. (1980). "How Bank Marketers View their Jobs". The Bankers' Magazine (USA), Vol. 163, pp. $35-40$.

[14] Berry, L.L (1986) "Big Ideas in Service Marketing”, Journal of Consumer Marketing, Spring, PP.47-51

[15] Bolton, R. N. (1998). A Dynamic model of the Duration of the Customer's Relationship with a Continuous Service Provider. Marketing Science, 17(1), 45-66.

[16] Carson, D., Gilmore, A., Cummins, D., O'Donnell, A. and Grant, K. 1998. Price Setting in SMEs: Some Empirical Findings, Journal of Product \& Brand Management, 7(1):74-86.

[17] Easingwood, C. and Storey, C. 1997. Distribution Strategies in the Financial Services Sector', Journal of Financial Services Marketing, 2(3):211-224

[18] Ennew, C., Banerjee, A. and Li, D. 2000. Managing Word of Mouth Communication: Empirical Evidence from India', International Journal of Bank Marketing,18(2):75-83.

[19] Epetimehin, F. (2011). Achieving competitive advantage in insurance industry: The impact of marketing innovation and creativity. European Journal Of Social Science, 19(1), 123-127.

[20] Fahy, J., Graham, H., Cox, T. and Beracs, J. 2000. The Development and Impact of Marketing Capabilities in Central Europe', Journal of International Business Studies, 31(1):63-81.

[21] Howcroft, J.B. 1993. Branch Networks and alternative Distribution Channels: Threats and Opportunities', International Journal of Bank Marketing, 11(6):26-31

[22] Kaplan, R. and Norton, D. 1992. The Balanced Scorecard Measures that Drive Performance', Harvard Business Review, 70(1):71-79.

[23] Kelly, D. and Storey, C. 2000. New Service Development: Initiation Strategies', International Journal of Service Industry Management, 11(1):45-62.

[24] Levie, D. (2006). Capability reconfiguration: An analysis of incumbent responses to technology change. Academy of Management Executive, 31(1): pp. 153-174.

[25] Levitt, T. 1981. Marketing Intangible Products and Product Intangibles', Harvard Business Review, 59(3):94-102.

[26] Mehta, S. (2010) "Personal Selling -A Strategy for promoting Bank Marketing"State Bank of India Monthly Review.

[27] Narver, J. and Slater, S. 1990. The Effect of a Market Orientation on Business Profitability', Journal of Marketing, October:20-35.

[28] O’Malley, L. and Patterson, M. 1998. Vanishing Point: The Mix Management Paradigm Re-Viewed', Journal of Marketing Management, 14:829-851.

[29] Pour, B. S., Nazari, K. and Emami, M. (2013). " The effect of marketing mix in attracting customers: Case study of Saderat Bank in Kermanshah Province". African Journal of Business Management, 7(34): 3272-3280. Radhakrishnan, S. (1987). "Marketing of Banking Services, Constraints, Challenges and Strategy". The Journal of Bank Marketing, Vo1.16, No.1, $15-23$.

[30] Raduan, C. R, Jegak, C., Haslinda \& Alimin L. L. (2009). A conceptual frame work of the relationship between organizational resources, capabilities, system, competitive advantage and performance. Journal of International Studies, Issue 12, Oct 2009.

[31] Ravisankar, T.S. (1985). "Marketing Strategies and Planning for Business Growth in Banks". SBZ Monthly Review, Vo1.16, No.2, 27-32 Saxena, K.K. (1988). "Bank Marketing: Concepts and Applications". New Delhi: Skylark Publications

[32] Singh, J.D. (1985), "Bank Marketing in India". International Journal of Bank Marketing, Vol.3, No.2, 48- 63.

[33] Turnbull, P.W (1982). The Role of the Branch Bank Manager in the Marketing of Bank Services, European Journal of Marketing, Vol. 16 No. 3, pp. 31-36.

[34] Zeithaml, V, Parasuraman A. and Berry, L. 1985) Problems and Strategies in Services Marketing, Journal of Marketing, 49, (Spring):33-46. [35] Zeithaml, V. 1988. Consumer Perceptions of Price, Quality, and Value: A Means-End Model and Synthesis of Evidence, Journal of Marketing, 52 (July):2-22

[36] Zeithaml, V., Berry, L. and Parasuraman, A. 1988.Communication and Control Processes in the Delivery of Service Quality, Journal of Marketing, 52 (April):35-48.
[37] Zheng Zhou, K., Brown, J. R., \& Dev, C. S. (2009). Market orientation, competitive advantage, and performance: A demand-based perspective. Journal Of Business Research, 62(2009), 1063-1070.

[38]

http://www.investopedia.com/terms/d/debtfinancing.asp\#ixzz4ivCgz3Qi

[39] https://en.wikipedia.org/wiki/List of banks in Bangladesh

[40] https://www.bb.org.bd/sme/index.php

[41] https://www.marketing91.com/service-marketing-mix/

[42] https://journal.ugm.ac.id/gamaijb/article/view/9286

[43] https://es.scribd.com/document/294538216/Historia-Del-Marketin

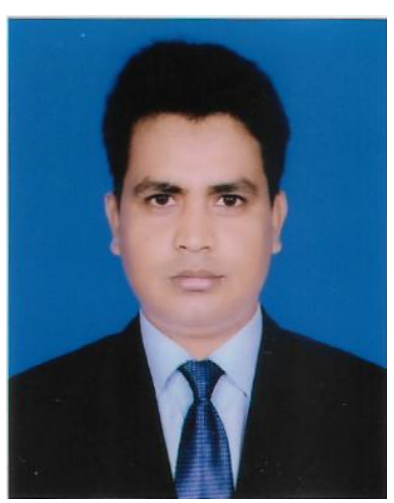

Author Profile: I am Banker by profession and research is my passion. have completed BBA \& MBA from University of Chittagong, Bangladesh. I have also completed professional course Junior Associate of the Institute of Bankers, Bangladesh (JAIBB) and Diplomaed Associate of the Institute of Bankers, Bangladesh (DAIBB). At present, I am doing part time research work and studying M.phil under schoo of Business at Bangladesh Open University. I have research interest on Service Marketing and SME financing. 